\title{
WIARA W LISTACH ŚW. BAZYLEGO WIELKIEGO
}

Postać Bazylego Wielkiego (†379) stanowi swoisty klucz do poznania doświadczenia życia chrześcijańskiego i konkretyzacji wiary w przepowiadaniu. Tematyka wiary w refleksji tego Ojca Kościoła z pewnością może być analizowana w różnych perspektywach. Biskup Cezarei Kapadockiej podejmował przede wszystkim zagadnienia treści Credo, polemizując z błędnowiercami i formułując właściwą doktrynę. W dialektyce pomiędzy doktryną Wielkiego Kościoła a herezjami pojawiały się szczegółowe zagadnienia, stanowiące przedmiot ówczesnych zażartych dyskusji. To właśnie one w głównej mierze odcisnęły swoje piętno na działalności i pismach Kapadocczyka. Badacze spuścizny Bazylego zwracali uwagę na kwestie dotyczące wiary w jego pismach dogmatycznych i ascetycznych. Korespondencja była w tych analizach zwykle pomijana lub traktowana marginesowo. $Z$ pewnością niesłusznie, bo przecież w Listach biskupa kapadockiego pojawiają się dyskusje dotyczące konkretnych kontrowersji doktrynalnych, znajdują swoje odbicie problemy wspólnot oraz widoczna jest szczera i niezachwiana wiara ich autora.

1. U źródeł wyznania wiary. Na spuściznę literacką Bazylego składają się traktaty dogmatyczne ${ }^{1}$, liczne mowy ${ }^{2}$ i kazania, pisma ascetyczne ${ }^{3}$, oraz

* Dr hab. Mieczysław Celestyn Paczkowski OFM, prof. UMK - kierownik Zakładu Patrologii i Antyku Chrześcijańskiego na Wydziale Teologicznym Uniwersytetu Mikołaja Kopernika w Toruniu; e-mail: celestyn@umk.pl.

${ }^{1}$ Wynikiem ostrej polemiki z drugą już generacją arian były dwa dzieła teologiczne: Adversus Eunomium i De Spiritu Sancto. W pierwszym dziele, powstałym w latach 363-365, Bazyli oskarża Eunomiusza - biskupa Kyziku nie tylko o herezję, ale i bezprawne zastępowanie terminologii biblijnej słownictwem filozoficznym. Dzieło O Duchu Świętym powstało ok. 375 r. jako odpowiedź Bazylego na głosy krytyki związane z użyciem przez niego nowej formy doksologii. Jest to prawdopodobnie zapis autentycznych dyskusji prowadzonych z Eustacjuszem z Sebaste i Pojmeniuszem. Autor dzieła dotyka nie tylko problemów teologicznych, ale także sfery życia duchowego.

${ }^{2}$ Warto tu wspomnieć przede wszystkim o Mowie do młodzieńców o korzyściach z czytania ksiażek pogańskich (De legendis gentilium libris, CPG 2867), w której Bazyli zachęcał do korzystania z osiaggnięć kultury antycznej, por. tłum. R. Andrzejewski, VoxP 32 (2012) t. 57, 895-921.

${ }^{3}$ Rozliczne pisma ascetyczne autorstwa Bazylego lub przypisywane mu stanowią podwaliny życia monastycznego i ascetycznego Wschodu. Są to często pisma o charakterze okazjonalnym. Należy uznać za autentyczne Reguły moralne (Moralia) ułożone w okresie pierwszych doświadczeń życia monastycznego przez Kapadocczyka. Liczą one 80 reguł życia chrześcijańskiego, które poprzedzają surowe w tonie dwie „zachęty” (Prologi). W formie pytań i odpowiedzi Bazyli zredago- 
obszerna korespondencja ${ }^{4}$. Po śmierci Atanazego z Aleksandrii (373) to biskup Cezarei Kapadockiej staje się czołowym obrońcą wyznania wiary z Nicei i wokół niego gromadzą się zwolennicy tej formuły. On sam znalazł się dosłownie w centrum konfliktów, które wstrząsały ówczesnym chrześcijaństwem, w okresie bardzo złożonym i trudnym w życiu i historii Kościoła powszechnego. Mimo pogarszającego się zdrowia, co powodowało częste niedyspozycje, aż do końca stawia czoła atakom na czystość wiary i wypełnia to, co należało w owym czasie do najważniejszych obowiązków biskupa. Swoje najlepsze strony odsłania głosząc prawowierną doktrynę, polemizując z błędnowiercami i rozwijając zasady monastycyzmu. Zbiór listów przypisywanych Bazylemu to obfite i cenne źródło informacji o dziejach Kościoła w IV wieku ${ }^{5}$ Jest to także skarbnica zawierająca wiele przyczynków do biografii wielkiego Kapadocczyka ${ }^{6}$.

Źródła epistolarne ukazują w całej pełni, że biskup Cezarei starał się usilnie o utrzymanie jedności wiernych w Kościele wbrew naporowi zracjonalizowanych i niewłaściwych formuł doktrynalnych ${ }^{7}$, jak również proariańskiej polityce dworu cesarskiego ${ }^{8}$. To właśnie w tym niespokojnym okresie ${ }^{9}$, zaczęto podkreślać czystą i prostą wiarę w Boga. U Kapadocczyka wyróżnia się kwestia pneumatologiczna, gdyż odnośnie do formuł wiary traktujących o Duchu

wał Reguły krótsze i Reguly dluższe. Te dwa zbiory Regut bardzo precyzyjnie nakreślają obraz „doskonałego chrześcijanina" (mnicha) i jego zachowanie się w różnych sytuacjach. Poświęcenie się

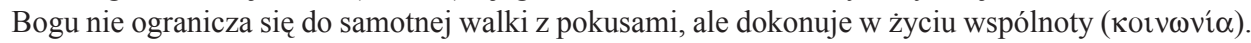

${ }^{4}$ Listy stanowią bardzo cenny dokument intensywnych kontaktów i działań podejmowanych przez Bazylego. Różnią się one między sobą formą i treścią. Niektóre stanowią niewielkie traktaty dogmatyczne, a inne zasłużyły nawet na miano „kanonicznych”. Najwięcej jest jednak listów o charakterze moralizująco-ascetycznym. Najczęściej Listy Bazyliańskie są grupowane wg ich wspólnych cech (por. Quasten II 224-228). Nie brak jednak problemów związanych z autorstwem i chronologią. W kolekcji epistolarnej biskupa Cezarei nie brak pism o wyrafinowanym stylu, by mogły uchodzić wyłącznie za wymianę korespondencji. Yves Courtonne klasyfikuje Listy wg trzech kategorii: listy poprzedzające episkopat Kapadocczyka (Epistulae 1-46), napisane w okresie pełnienia posługi biskupiej (Epistulae 47-291) oraz te których datacja jest niepewna lub niemożliwa (Epistulae 292-365). Jest to w gruncie rzeczy podział korespondencji Bazylego, przyjęty za J. Migne (PG 32).

${ }^{5}$ Większość z 366 Listów pochodzi z okresu posługi biskupiej. Powstały one w latach 370-378. Listy te stanowią $2 / 3$ całego zbioru. Trudno jednak ustalić datację wielu z nich; istnieją też wątpliwości względem ich autentyczności, por. Quasten II 223; zob. także Y. Courtonne, Un témoin du IV siècle oriental. Saint Basile et son temps d'après sa correspondance, Paris 1973; B. Gain, L'Église de Cappadoce au IV siècle d'après la correspondance de Basile de Césarée, Roma 1985.

${ }^{6}$ Por. E. Buonaiuti, Attraverso l'epistolario di S. Basilio, „Rivista Storico-Critica delle Scienze Teologiche" 4 (1908) 131.

${ }^{7} \mathrm{O}$,przeracjonalizowanie wiary” oskarżano sektę Eunomiusza. Por. przede wszystkim E. Van Den Bussche, La part de la dialectique dans la théologie d'Eunome, le technologue, RHE 40 (19441945) 47-72.

${ }^{8}$ Chodzi tu głównie o cesarza Walensa, por. Quasten II 208.

${ }^{9}$ Por. przede wszystkim M. Simonetti, La crisi ariana nel IV secolo, SEA 11, Roma 1975. 
Świętym ${ }^{10}$ Bazyli pozostawał ostrożny. Preferował te sformułowania, które poprzez swoją biblijność odsuwały konieczność narzucania określeń, z którymi nie wszyscy się zgadzali. Konsekwentnie jednak zwalczał pneumatomachów ${ }^{11}$, utrzymując, że również Paraklet jest Bogiem i wraz z Ojcem i Synem winien być wyznawany i uwielbiany ${ }^{12}$. Jednocześnie Kapadocczyk brał pod uwage „szeroki front heretycki”13. Potrafił przeciwstawić się z gorliwością i odwagą także błędnowiercom negującym prawdę o równości natury Ojca i Syna ${ }^{14}$.

Bazyli nawiązuje do teologii, która uformowała się po soborze w Nicei, według której człowiek odnajduje Boga idąc drogą kontemplacji wspaniałości $\mathrm{i}$ harmonii świata ${ }^{15}$. Dopełnieniem tego procesu jest wnikanie we wnętrze własnej duszy i bliskość z Bogiem ${ }^{16}$. Nic więc dziwnego, że i nasz autor stwierdził: „Jedynym doskonałym dobrem jest tylko Bóg”"17. Boska natura jest określana przez Bazylego jako „niewidzialna” i „nieskończona” ${ }^{18}$, przekraczająca wszelkie wyobrażenia ${ }^{19}$. Pojęcie transcendencji Boga stoi u podstaw ważnych zasad teologii, ujętych według perspektywy biblijnej. Tylko doskonałe poznanie Boga w wieczności napełnia człowieka szczęściem bez granic ${ }^{20}$.

Należy jednak mieć na uwadze, że dla biskupa Cezarei wszyscy powinni być pouczeni w kwestiach wiary chrześcijańskiej. Pouczenia o charakterze

${ }^{10}$ Tak jest w dziele $O$ Duchu Świętym (powstałym ok. 375). Była to odpowiedź Bazylego na głosy krytyki związane z użyciem przez niego nowej formy doksologii. Kapadocczyk dotyka nie tylko problemów teologicznych, ale także sfery życia duchowego.

${ }^{11} \mathrm{Na}$ określenie tych, którzy negowali bóstwo Parakleta (czyli bluźniących przeciwko Duchowi Świętemu lub „wojujących” z Nim) używane były zamiennie różne nazwy (pneumatomachowie, tropikowie, macedonianie, anomejczycy, którym przewodzili Aecjusz i Eunomiusz).

${ }^{12}$ Por. Basilius Caesarensis, De Spiritu Sancto XI 27, ed. B. Pruche, SCh 17bis, Paris 1968, 155, tłum. A. Brzóstowska: Św. Bazyli Wielki, O Duchu Świętym, wstęp J. Naumowicz, Warszawa 1999, 120: „Nie można bowiem czcić Ojca, jeśli nie w Duchu Świętym, ani nie można wzywać Ojca, chyba, że w Duchu przybranego synostwa (por. Rz 8, 15)".

${ }^{13}$ Opinia wydawcy traktatu De Spiritu Sancto B. Pruche, w: SCh 17bis, 7 i 341, nota 4.

${ }^{14}$ Por. Basilius Caesarensis, Epistula 9, 3; 52, 1-3; Adversus Eunomium I 20.

${ }^{15}$ Dla Bazylego (In Hexaemeron hom. 6, 1) cały świat jest swego rodzaju „szkołą dusz” mająca doprowadzić człowieka do poznania Boga, por. T. Špidlík, La spiritualità dell'Oriente cristiano. Manuale sistematico, OCA 206, Roma 1985, 293.

${ }^{16} \mathrm{~W}$ pierwszych wiekach chrześcijaństwa powtarzano, że błogosławiony był ten, kto posiadał Boga, por. Apocalipsis Petri (Akhmim) 3; zob. także Augustinus Hipponensis, De vita beata II 11.

${ }^{17}$ Basilius Caesarensis, In Psalmos hom. 33, 7, PG 29, 368AB, thum. własne.

${ }^{18}$ Tenże, In Hexaemeron hom. 1, 3, ed. S. Giet, SCh 26, Paris 1968, 100, thum. własne. O wpływach platońskich, stoickich i perypatetyckich na tego typu koncepcje Boga por. Y. Courtonne, Saint Basile et l'hellénisme. Étude sur la rencontre de la pensée chrétienne avec la sagesse antique dans l'Hexaéméron de Basile le Grand, Paris 1934, 20-22.

${ }^{19}$ Por. Basilius Caesarensis, In Hexaemeron hom. 1, 11; 2, 3.

${ }^{20} \mathrm{Wg}$ Jana Chryzostoma (Quod nemo laeditur nisi a se ipso 10, ed. A.-M. Malingrey, SCh 103 , Paris 1964, 106-112, thum. K. Kochańczyk: Św. Jan Chryzostom, Kto sam sobie nie szkodzi, temu nikt zaszkodzić nie może, w: Bóg i zło. Pisma Bazylego Wielkiego, Grzegorza z Nyssy i Jana Chryzostoma, BOK 23, Kraków 2004, 112) człowiek krzywdzi sam siebie, gdy odrzuca Boga, który jest największym dobrem i szczęściem. 
katechetycznym rozwijały się na bazie Pisma Świętego ${ }^{21}$ i według schematu podanego przez symbol wiary 22 . W IV w. panowało przekonanie, że wszystko, co dotyczy prawd Bożych, osoby Chrystusa Pana i tajemnicy zbawienia zawarte jest w natchnionych księgach ${ }^{23}$. Nie było więc najmniejszej trudności z odwoływaniem się do przeświadczenia, że Biblia jest wystarczającym źródłem objawienia, chociaż istnieją nie spisane tradycje apostolskie. W większości chodziło jednak o fakty dotyczące liturgii, dyscypliny kościelnej lub obyczajów $^{24}$. Biblia stanowi „boskie przesłanie”, na co wskazują pełne szacunku określenia Pisma Świętego jako „Bożego pouczenia”, „słowa nauki”, „,nauki Pańskiej”25. Każdy wierzący powinien „uczyć się wiele z Pisma”26, z którego należy przekazywać „każde słowo"27. Z kolei na mnichu ciążył obowiązek uczenia się na pamięć natchnionych tekstów, przede wszystkim Psałterza ${ }^{28}$. To polecenie stanowiło jeden z podstawowych kanonów tradycji monastycznej ${ }^{29}$. Jednak nawet bez tego typu sformułowań Pismo Święte było dla mnichów podstawą edukacji, formacji i wykładnią postępowania, a więc swego rodzaju „podręcznikiem” życia ascetycznego. Zastosowanie Biblii w kręgach monastycznych miało z reguły znaczenie duchowo-ascetyczne, jednak zwraca też uwagę na kwestię przeżywania wiary i urzeczywistnienia jej przez chrześcijan.

Jako czołowy hierarcha Bazyli znalazł się w sytuacji, gdy musiał rozwiązywać pojawiające się problemy, wyjaśniać nieporozumienia, upominać i zachęcác ${ }^{30}$. W swojej korespondencji Bazyli z Cezarei przywołuje niejednokrotnie natchnione teksty. Jego listy o charakterze teologiczno-doktrynalnym $^{31}$ zawierają najwięcej cytatów z Pisma Świętego ${ }^{32}$. Nie znaczy to jednak,

${ }^{21} \mathrm{Na}$ temat triady ,,prorocy, ewangeliści, apostołowie” por. Basilius Caesarensis, De baptismo I 1, ed. U. Neri - J. Ducatillon, SCh 357, Paris 1989, 100; tamże I 2, SCh 357, 122; zob. także U. Neri, Basilio di Cesarea. Il battesimo. Testo, traduzione, introduzione e commento, Testi e ricerche di scienze religiose 12, Brescia 1976, 155-157 oraz noty.

${ }^{22}$ Por. Basilius Caesarensis, De baptismo I 1, 2.

${ }^{23}$ Por. P. Lengsfeld, Überlieferung, Tradition und Schrift in der evangelischen und katholischen Theologie der Gegenwart, Konfessionskundliche und kontroverstheologische Studien 3, Paderborn 1960, 120-121.

${ }^{24}$ Por. szeroką panoramę wg H. Campenhausen, Tradition and Life in the Church. Essays and Lectures in Church History, London 1968.

${ }^{25}$ Por. Neri, Basilio di Cesarea. Il battesimo, s. 204-207 oraz noty.

${ }^{26}$ Basilius Caesarensis, Regulae brevius tractatae 235, PG 31, 1240 B, thum. J. Naumowicz, w: Bazyli Wielki, Pisma ascetyczne: Reguły dluższe i Reguły krótsze, ŹM 6, Kraków - Tyniec 2011, 420.

${ }^{27}$ Por. tenże, De baptismo I 2.

${ }^{28}$ Por. U. Neri, Basilio di Cesarea. Opere ascetiche, Classici delle religioni UTET, Torino 1980, 368-369; zob. Basilius Caesariensis, Regulae brevius tractatae 61 i 95.

${ }^{29}$ Tego typu zalecenia pojawiają się w tradycji pachomiańskiej, por. Pachomius, Mandata 139140; zob. również Neri, Basilio di Cesarea. Opere ascetiche, s. 369, nota 202.

${ }^{30}$ Por. J. Gribomont, Basilio (santo), DIP I 1107.

${ }^{31}$ Taki charakter mają Epistulae $9 ; 52 ; 105 ; 113-114 ; 125 ; 129 ; 131 ; 159 ; 175 ; 210 ; 214 ; 226$; $251 ; 258 ; 261 ; 262 ; 361-364$.

${ }^{32}$ Por. Quasten II 226-227. 
że odnośników biblijnych brak w korespondencji o charakterze ascetycznym i moralnym ${ }^{33}$ lub liturgicznym ${ }^{34}$. Analiza jakiejkolwiek kwestii w korespondencji Bazylego daje wrażenia dotykania pulsu ówczesnej epoki, gdy dyskusje teologiczne stanowiły bezwzględny priorytet.

Prawdy objawione w różny sposób znajdują się na kartach natchnionych ksiąg, lecz aby w nie wierzyć potrzeba posiłkować się czymś, co pochodzi spoza nich i jest kryterium ich interpretacji. Nic więc dziwnego, że obok Biblii Kapadocczyk stawia Tradycję ${ }^{35}$. To do niej należy się odnosić w ocenie prawowierności. Tradycję stanowi przekaz apostolski wyrażony przede wszystkim w wyznaniu wiary z Nicei. To zresztą wzór dla wszystkich innych wyznań wiary. Zbawienie dokonuje się w imię Trójcy Przenajświętszej, ponieważ:

„,chrzest udzielony nam został przez Zbawiciela w imię Ojca, i Syna, i Ducha Świętego, składamy wyznanie wiary zgodne z tym chrztem"36.

Poprzez przekaz biblijny i nauczanie Kościoła poznaje się to, co jest konieczne do zbawienia. W swojej korespondencji Bazyli używa znaczącego

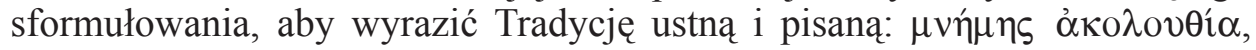
czyli naśladowanie, odwołanie do pamięci:

„Nie domagamy się niczego nowego [...]. Pamiętamy [...], pouczeni przez naszych Ojców, których zapytywaliśmy o to, oraz na podstawie listu ${ }^{37}$, jaki do tej pory przechowywany jest u nas" ${ }^{38}$.

Pamięć to jednak nie tylko kwestia teoretyczna, ale także praktyczna. Kapadocczyk zwraca się do mnichów:

„Wzywamy was, iżbyście mieli na pamięci wiarę Ojców, nie dali się zachwiać przez tych, którzy usiłują zwieść was w waszej samotni, bo wiedzcie, że ścisłe przestrzeganie reguły życia samo przez się niewiele jest warte, jeśli nie jest ono rozświetlone wiarą w Boga, ani też wierne na nią przystanie, ale bez dobrych uczynków, nie będzie mogło zaskarbić wam względów u Pana. Jeśli człowiek w pełni ma stać się człowiekiem Bożym, a życie nasze nie

${ }^{33}$ Quasten (II 226) wylicza w tej grupie Epistulae 2; 10-11; 14; 18; 22-26; 49; 65; 83; 85; 97; $106 ; 112 ; 115-116 ; 161 ; 173-174 ; 182-183 ; 197 ; 219 ; 220-222 ; 240 ; 246 ; 249 ; 251 ; 259 ; 277 ; 283$; 291-299; 366.

${ }^{34}$ Do tej grupy należą Epistulae 207 i 93; por. Quasten II 227.

${ }^{35} \mathrm{O}$ Tradycji apostolskiej i eklezjalnej u Bazylego por. Gain, L'Église de Cappadoce, s. 326-330.

${ }^{36}$ Basilius Caesarensis, Epistula 159, 2, ed. Y. Courtonne: Saint Basile. Lettres. Texte établi et traduit, II, Paris 1961, 86, thum. W. Krzyżaniak: Św. Bazyli Wielki, Listy, Warszawa 1972, 174.

${ }^{37}$ Autorstwa Dionizego, papieża (259-268). Bazyli pisze o tym biskupie Rzymu, że odznaczał się ,wiarą prawowierną i innymi cnotami” (Epistula 70, ed. Courtonne, I, Paris 1957, 165, thum. Krzyżaniak, s. 113).

${ }^{38}$ Basilius Caesarensis, Epistula 70, ed. Courtonne, I, 165, tłum. Krzyżaniak, s. 113; zob. A. Penati Bernardini, La fede nei Padri Cappadoci, w: La fede nei Padri della Chiesa, ed. S. Panimolle, Dizionario di spiritualità biblico-patristica 22, Roma 1999, 204. 
ma być chrome przez jakieś niedostatki, to potrzebne są oba wspomniane poprzednio usiłowania" ${ }^{39}$.

Bazyli przestrzegał więc przed życiem, którego ewangelicznego charakteru nie poświadczają uczynki.

Przekazywanie wiary to świadome i osobiste przyjęcie przez chrześcijanina dziedzictwa strzeżonego w łonie Kościoła. Tradycja ustna i pisana to dwa równoległe kanały przekazu doktrynalnego i duchowego bogactwa wspólnoty Chrystusowej. Znaczący pod tym względem jest fragment traktatu O Duchu Świętym:

„Z doktryn i nauczania strzeżonych przez Kościół, jedne pochodzą z pisemnego nauczania, drugie przekazane nam jako misterium przejęliśmy $\mathrm{z}$ tradycji apostolskiej. Jedne i drugie mają tę samą moc w prawowitej wierze. I nikt im się nie sprzeciwi, nawet ten, kto słabo się orientuje w obrzędach kościelnych. Gdybyśmy usiłowali odrzucić niepisane zwyczaje jako mające niewielkie znaczenie, bezwiednie narazilibyśmy na szkodę Ewangelię w jej zasadniczych punktach, a co więcej, przekształcilibyśmy nauczanie w nazwę o pustym dźwięku"

W formułach wiary porządek imion Bożych powinien pozostać niezmien$n y^{41}$. Pełnię poznania otrzymamy dopiero w przyszłym świecie:

„[gdy] stanie się możliwe rozwiązanie wątpliwości, danie najobszerniejszego świadectwa pochodzące z Pisma [i] potwierdzenie każdej właściwej formy wiary" ${ }^{\prime 2}$.

Obecnie natomiast, jak precyzuje Bazyli, odwołując się do kwestii zbawczego imienia Bożego:

„w kwestii nazw jest dla nas wystarczające uznać te [z nich], które otrzymaliśmy z Pisma Świętego. Tak unikniemy nowości na tym polu. Nie w wymyślaniu określeń jest nasze zbawienie, ale we właściwym wyznawaniu Boskości, w którą wierzymy ( $\pi \iota \sigma \tau \varepsilon v ́ \omega)^{\prime \prime 33}$.

Należy jednak pamiętać, że:

„wiara $[\ldots]$ jest tym, co nas zbawi, kiedy, jak Apostoł powiada, jest «przez miłość czynna» (Ga 5, 6)" ${ }^{\prime 4}$.

Mimo faktu, że Objawienie pomaga w opisywaniu Boga, jednak mówienie o Jego przymiotach i tajemnicach jest rzeczą niezwykle trudną. Widać to na przykładzie

\footnotetext{
${ }^{39}$ Basilius Caesarensis, Epistula 295, ed. Courtonne, III, Paris 1966, 170, thum. Krzyżaniak, s. 351.

${ }^{40}$ Tenże, De Spiritu Sancto XXVII 66, SCh 17bis, 232-233, tłum. Brzóstowska, s. 175.

${ }^{41}$ Por. tenże, Epistula 175.

${ }^{42}$ Tenże, Epistula 125, 3, ed. Courtonne, II, 34, tłum. własne.

${ }^{43}$ Tenże, Epistula 175, ed. Courtonne, II, 112, tłum. własne.

${ }^{44}$ Tenże, Epistula 295, ed. Courtonne, III, 170, tłum. Krzyżaniak, s. 351.
} 
rozważań o ojcostwie Boga, bowiem ,jest nieosiągalny w rozważaniach”45. To kolejne ogniwo mysterium fidei, wobec którego najlepiej jest milczećt ${ }^{46}$. Jednakże refleksja nad formułami wiary jest potrzebna, bo to ciagły wzrost i dojrzewanie tego, co było przekazane w stanie zarodkowym w kręgu rodzinnym ${ }^{47}$.

Wiara nie potrzebuje ludzkiego dociekania i dowodzenia. Zbytnia ciekawość jest przyczyną odstępstwa. Dlatego Kapadocczyk zaleca:

„Prosimy, tych którzy złożyli swoją nadzieję w Chrystusie, aby nie podejmowali dociekań z większej ciekawości, wykraczając poza dawną wiarę"48.

Przed zdeformowaniem treści treści Credo chronią bowiem pasterze wspólnot:

„To rzecz godna pochwał najwyższych, że bogobojnościom waszym dany został z łaski Pana dar rozróżnienia fałszu od tego, co prawe i czyste, dar głoszenia wiary Ojców bez jakiejkolwiek małoduszności, tej wiary, którą my również przyjęliśmy i którą uznajemy jako naznaczoną apostolskimi cechami, i na którą przystajemy jak i na wszystkie dogmaty, w dokumencie soboru określone kanonicznie i prawomocnie"49.

Broniąc się przed oskarżeniami niewłaściwego sformułowania wiary ${ }^{50}$, Kapadocczyk wspomina w innym liście, jak to spędzał z braćmi noc na modlitwie $^{51}$, ,i sam głosząc Boga i słuchając o Nim kornie zawsze bez szukania kości niezgody"s2.

${ }^{45}$ Tenże, De Spiritu Sancto XXI 53, SCh 17bis, 211, thum. Brzóstowska, s. 159. Twierdzenie to odnosi się do każdej z Osób Trójcy Przenajświętszej. Biskup Cezarei Kapadockiej (De fide 3, PG 31, 684 B, tłum. Naumowicz, w: Bazyli Wielki, Pisma ascetyczne: Wstęp do Zarysu ascezy, O sqdzie Bożym, O wierze, Reguty moralne, ŹM 5, Tyniec - Kraków 2011, 97-98) wyjaśnia to następująco: „Jeśli ktoś powie «Bóg», nie ukazuje znaczenia, jakie ma «Ojciec», a w słowie «Ojciec», nie ma tego, co znaczy «Stworzyciel»»"

${ }^{46}$ Por. tenże, Adversus Eunomium III 7. Na temat argumentu ex silentio zob. B. Sesboüé, w: SCh 299, Paris 1982, 174, nota 2. Wg Klemensa Aleksandryjskiego milczenie znamionowało ,prawdziwego gnostyka" czyli ugruntowanego w dobrym i doskonałego chrześcijanina. Por. R Mortley, The Theme of Silence in Clement of Alexandria, JTS 24 (1973) 197-202.

${ }^{47}$ Por. Basilius Caesarensis, Epistula 223, 3, ed. Courtonne, III, 12, tłum. Krzyżaniak, s. 253: „Jedna i ta sama nauka wiary rozrasta się dzięki czynionym postępom”. Grzegorz z Nyssy (In Hexaemeron hom. (proem.), PG 44, 61A - 64A) mówi, że Bazyli doprowadził do wzrostu i uczynił drzewem owo „nasienie gorczyczne”, które Mojżesz rzucił w ziemię. Na temat tego porównania zob. G.I. Gargano, La teoria di Gregorio di Nissa sul Cantico dei Cantici. Indagine su alcune indicazioni di metodo esegetico, OCA 216, Roma 1981, 108.

${ }^{48}$ Basilius Caesarensis, Epistula 175, ed. Courtonne, II, 112, thum. własne.

${ }^{49}$ Tenże, Epistula 92, 3, ed. Courtonne, I, 203, thum. Krzyżaniak, s. 131.

${ }^{50}$ Świadectwo stanowi Epistula 204 z 375 r. (por. Courtonne, II, 162, nota 2). Echo podobnych oskarżeń można znaleźć w listach 55 i 126 (por. Courtonne, I, 155; II, 35).

${ }^{51}$ Por. Basilius Caesarensis, In Psalmos hom. 1, 1-2, PG 29, 212A - 213 C.

${ }^{52}$ Tenże, Epistula 223, 5, ed. Courtonne, III, 14, tłum. Krzyżaniak, s. 255. 
2. Prostota wiary i jej przeciwnicy. Dla kapadockiego biskupa ,prostota" to główna charakterystyka Biblii i zasad wiary. To powód, dla którego taka powinna być również lektura natchnionych stronic ${ }^{53}$ i przyjmowanie prawd wiary. Kierunek ten wskazuje sam Bóg, który ze swej natury, jest „,niezłożony" ${ }^{54}$. Człowiek otrzymał od swego Stwórcy tę cechę, jednak utracił ją przez grzech ${ }^{55}$. Należy więc powrócić do owej pierwotniej, „,rajskiej prostoty" i odkrywać ją w Słowie Bożym ${ }^{56}$. Bazyli uwydatnia, że w opowiadaniu o pierwszych dniach stworzenia Bóg wymawia „krótkie słowo” i „daje ścisłe polecenia" ${ }^{57}$. Zresztą natura Słowa Bożego jest taka, iż może być ono przyjęte i zrozumiałe dla każdego, kto szczerze poszukuje prawdy ${ }^{58}$. „Niech przynajmniej prostota wiary będzie silniejsza od dowodów rozumowych"59, apeluje Bazyli. Temu, kto ma wiare dostatecznie silna, wystarczy pojedynczy odnośnik do ksiąg świętych, aby był przekonany o prawdziwości doktryny ${ }^{60}$. Kapadocczyk uważał, że im więcej tekstów biblijnych, tym lepiej ukazuje się jedna myśl Pisma Świętego ${ }^{61}$. Uciekanie się do zawiłych wyjaśnień egzegetycznych świadczy o słabości wiary. Kto nie szuka prawdy w prostych zasadach dogmatów schodzi na bezdroża błędu ${ }^{62}$. Należy więc najpierw uwierzyć w prostocie serca Pismu Świętemu, a dopiero później wgłębiać się w znaczenie tekstów biblijnych.

Tak więc Słowo, „które wychodzi z ust Bożych”63 jest podstawą refleksji teologicznej. To ono jest najwyższą normą dyskursu teologicznego, ponieważ w sposób doskonały i zrozumiały wyraża dogmaty, chociaż nie można mówić o pełnej zgodności każdej ze stronic biblijnych ${ }^{64}$. W ślad za prostą egzegezą (dosłowną i typologiczna) idzie prostota formuł doktrynalnych. Słowo Pisma stanowi „miarę określania prawdy” ${ }^{65} \mathrm{w}$ refleksji teologicznej. Tak więc, nawet jeśli jakieś określenie wydaje się trafniejsze z punktu widzenia rozumowego,

${ }^{53}$ Por. tenże, Adversus Eunomium I 11. Por. M. Girardi, ,,Semplicità ” e ortodossia nel dibattito antiariano di Basilio di Cesarea: la raffigurazione dell'eretico, VigCh 15 (1978) 51-74.

${ }^{54}$ Por. Basilius Caesarensis, Adversus Eunomium I 11; I 25.

${ }^{55}$ Por. tenże, In Hexaemeron hom. 3, 7.

${ }^{56}$ Bazyli (In Psalmos hom. 7, 6) twierdzi, że bez trudu można znaleźć niezliczone przykłady „biblijnej prostoty”.

${ }^{57}$ Basilius Caesarensis, In Hexaemeron hom. 5, 2, SCh 26, 284, tlum. własne.

${ }^{58}$ Bazyli jest zdania, że dla człowieka wierzącego wystarczy tylko jeden fragment Pisma Świętego, aby rozwiać wszelkie wątpliwości, por. P. Scazzoso, San Basilio e la Sacra Scrittura, „Aevum” 47 (1973) 218 oraz noty.

${ }^{59}$ Basilius Caesarensis, In Hexaemeron hom. 1, 10, SCh 26, 130, thum. własne. Bazyli był pełen podziwu dla cudów stworzenia, por. przede wszystkim F. Onorati, Il pathos di thaumazein: La meraviglia nell'Esamerone di Basilio di Cesarea, „Studia Patavina” 49 (2002) 283-336.

${ }^{60}$ Por. Scazzoso, San Basilio e la Sacra Scrittura, s. 218.

${ }^{61}$ Por. Basilius Caesarensis, De fide 3.

${ }^{62}$ Por. tenże, In Psalmos hom. 115, 2.

${ }^{63}$ Por. tenże, De baptismo II 4; II 8.

${ }^{64}$ Por. tenże, De fide 6.

${ }^{65}$ Tenże, Adversus Eunomium I 1, ed. B. Sesboüé, SCh 299, 142, tłum. własne. 
samo w sobie jest niewystarczające, gdyż pierwszeństwo mają zawsze proste sformułowania biblijne ${ }^{66}$.

W świetle prawdy objawionej należy oceniać nie tylko pojedyncze sformułowania, ale także wszelkie syntezy doktrynalne. W tym względzie osąd Kapdocczyka jest bardzo radykalny. Każdy wywód teologiczny, jeśli nie jest poparty tekstami natchnionymi ${ }^{67}$, powinien być traktowany $\mathrm{z}$ ostrożnościa, a nawet odrzucony jako dzieło „dzieci gniewu” (por. Ef 2, 3). Wolność spekulacji w kwestiach teologicznych powinna być ograniczona przez posłuszeństwo Chrystusowi jako „synowie światłości”68. Słowo Zbawiciela to jednocząca siła, której wszyscy wierzący powinni być posłuszni ${ }^{69}$.

To Pismo Święte sugeruje metody refleksji teologicznej. Tylko za pomocą terminologii biblijnej dają się wyrazić treści doktrynalne i doświadczenie wiary. Kapadocczyk zauważa jednak, że dzieje się to ,jakby w zwierciadle, niejasno" (1Kor 13,12), w sposób ograniczony, choć dla istoty ludzkiej wystarczający. Pełnia poznania będzie możliwa tylko w przyszłym świecie ${ }^{70}$.

Treści wiary sformułowane w Piśmie Świętym nie opierają się na pojedynczych wyrażeniach. Słowo Boże jest przywoływane w swoim niewyrażalnym bogactwie i niesłychanej różnorodności. Zniekształconym odbiciem tej metody jest toporna technika manipulowania tekstami natchnionymi ${ }^{71}$, stosowana przez Ariusza i Eunomiusza oraz całą plejadę ówczesnych błędnowierców.

Bazyli stwierdza, że porzucenie prostej wiary niesie za sobą ogromne niebezpieczeństwo:

„Do końca byśmy nie doszli z dysputami, bo narzucający się wciąż pogląd przeciwny sprowadzałby nas coraz dalej, a w duszach ludzi prostych spowodowalibyśmy tylko zamęt przez wprowadzanie ujęć dziwacznych"72.

Swoje rozważania Bazyli kieruje ku fałszywym nauczycielom wiary. Kapadocczyk stwierdza z gorycza, że o Bożych tajemnicach mówi nawet ten, „kto ma duszę napiętnowaną tysiącami plam" "73. Nie mają oni prawa mówić innym o wierze ${ }^{74}$. Ojciec kapadocki mówił bez ogródek, że ówczesny Kościół przedstawiał obraz raczej mało budujący ${ }^{75}$. Widział bowiem:

${ }^{66}$ Problem dotyczy określenia „niezrodzony”, które odnosi się do osoby Syna Bożego. To kluczowy element dyskusji z eunomianami. Dla Bazylego (Adversus Eunomium I 1, SCh 299, 140-141, tłum. własne) więc tytuł „«niezrodzony» należy przemilczeć, ponieważ nie znajduje się z żadnym z fragmentów Pisma Świętego". Por. tenże, Epistula 223, 1.

${ }^{67}$ Por. tenże, Regulae brevius tractatae 269.

${ }^{68}$ Tamże 268, PG 31, 1268C, ŹM 6, 451.

${ }^{69}$ Por. tenże, De iudicio 1-3.

${ }^{70}$ Por. tenże, De fide 2.

${ }^{71}$ Por. tenże, Adversus Eunomium I 1.

${ }^{72}$ Tenże, Epistula 258, 2, ed. Courtonne, III, 102, tłum. Krzyżaniak, s. 310.

${ }^{73}$ Tenże, De Spiritu Sancto XXX 77, SCh 17bis, 258, thum. Brzóstowska, s. 194.

${ }^{74}$ Grzegorz z Nazjanzu poświęca tej kwestii całą Oratio 28 (PG 36, 11A - 26B).

${ }^{75}$ Por. Girardi, ,,Semplicità " e ortodossia, s. 57. 
„U wielu jakąś wielką i niezmierną niezgodność między sobą, jak też w stosunku do Bożych Pism [...]. Sami [zwierzchnicy Kościoła] pozostają między sobą w wielkim rozdarciu myśli oraz pojęć i zajmują krańcowo różne postawy wobec przykazań Pana naszego Jezusa Chrystusa: jak niemiłosiernie rozdzierają Kościół Boży i bezlitośnie wprowadzają w zamęt jego trzodę"76.

W pierwszym liście kanonicznym skierowanym do Amfilocha, biskupa Ikonium $^{77}$, w związku z delikatną kwestią chrztu heretyków, Bazyli wprowadza bardzo precyzyjne rozróżnienie:

„Dawni Ojcowie uważali, że tylko taki chrzest, należy przyjmować, który w niczym nie uchybia wierze, stąd jedne błędne nauki nazywali herezjami, inne schizmami, a jeszcze inne parasynagogami" ${ }^{\prime 78}$.

Z nich najgroźniejsza jest herezja, grupująca „tych, którzy odłączyli się zupełnie i odwrócili się od wiary" "79. Tego typu rozróżnienie stanowi unicum w rozważaniach Bazylego. Wyszczególnia on różne stopnie kontestacji prawdy wiary $^{80}$. Ponadto jako „,prywatne zgromadzenia" ${ }^{81}$ określano kręgi hołdujące niezdrowemu radykalizmowi ascetycznemu i kontestacji oficjalnego Kościoła.

Postawa Kapadocczyka nie była odosobniona. Synod biskupów w Antiochii nakazywał:

„[gdyby duchowny] tworzył własne zgromadzenia, ustawił własny ołtarz, i nie zważał na upomnienia biskupa, nie chciał okazać posłuszeństwa [...] należy go całkowicie pozbawić urzędu [...]. Gdyby trwał w uporze, powodując zamieszanie i rozłam w Kościele, należy go jako buntownika skarcić przy pomocy władzy świeckiej”\$2.

${ }^{76}$ Basilius Caesarensis, De iudicio 1, PG 31, 653A-B, thum. J. Naumowicz, w: Św. Bazyli, Pisma ascetyczne, I: Wstęp do zarysu ascezy, O sq̨dzie Bożym, O wierze, Reguly moralne, ŹM 5, Kraków - Tyniec 1994, 67.

${ }^{77} \mathrm{Na}$ temat tej postaci por. J.S. Voicu, Anfilochio d'Iconio, NDPAC I 290-291.

${ }^{78}$ Basilius Caesarensis, Epistula 188, 1 ed. Courtonne, II, 121, tłum. Krzyżaniak, s. 184. Odnośnie do problematyki poruszanej w tym liście por. M. Girardi, La terminologia di eresia, scisma e parasinagoga in Basilio di Cesarea, w: Basilio di Cesarea. La sua età, la sua opera e il basilianesimo in Sicilia, I, Messina 1983, 534-565.

${ }^{79}$ Basilius Caesarensis, Epistula 188, 1, ed. Courtonne, II, 121, thum. Krzyżaniak, s. 184.

${ }^{80}$ Por. M. Girardi, Nozione di eresia, scisma e parasinagoga in Basilio di Cesarea, VigCh 17 (1980) 49-77.

${ }^{81}$ Por. charakterystykę inicjatyw Lucjana z Antiochii wg Atanazego Wielkiego (Epistula ad Alexandrum 36). Synod w Gangrze w Paflagonii [Concilium Gangrense (ok. 340) can. 5, wyd. grecko-polskie, układ i opracowanie A. Baron - H. Pietras, tłum. A. Baron, ŹMT 37, Kraków $2006=$ SCL 1, 125-125*] potępia opuszczających zgromadzenia i gromadzących się prywatnie (por. Epistula synodalis, passim).

${ }^{82}$ Concilium Antiochenum (341) can. 5, SCL 1, 136-136*; por. P.F. Bradshaw, Kirchenordnungen, I: Altkirchliche, TRE XVIII 662-670; G. Bardy, Antioche (Concile et canons d'), DDC I 589-598. 
Sobór w Konstantynopolu (381) natomiast jasno sprecyzowal, że należy zwalczać tych, którzy „,oddzielili się od prawowitych biskupów i utrzymują osobne zgromadzenia" ${ }^{83}$.

Biskup Cezarei Kapadockiej wprowadza kwestię fałszywych nauczycieli

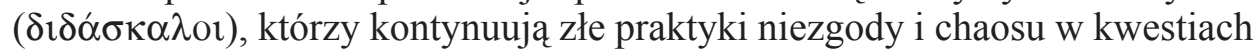
doktrynalnych ${ }^{84}$, przez co niszczą jedność wierzących i wprowadzają nienawiść i zamieszanie odnośnie do prawd wiary ${ }^{85}$. Ich fałszywa mądrość prowadzi do odrzucenia prawdy ${ }^{86}$, w jej jasnej i prostej formie ${ }^{87}$. Stąd prosta droga do herezji, pojmowanej jako sprzeniewierzenie się Tradycji i propagowanie błędnych formuł doktrynalnych ${ }^{88}$. Fałszywy nauczyciel przyjmuje niegodziwe nauki i rozsiewa je nieustannie ${ }^{89}$. Z konieczności należy go „odrzucić” i ,odciąć" od wspólnoty ${ }^{90}$. Natomiast specjalnej uwagi i odpowiedniego podejścia potrzebują słabi i chwiejni w wierze ${ }^{91}$.

Zwalczanie fałszywych nauczycieli polegało nie tylko na kontestowaniu ich błędów. Oskarżenie o herezję często łączyło się ze wskazaniem, iż życie błędnowiercy rozmijało się z przesłaniem ewangelicznym ${ }^{92}$, przez co stawał się on niewiarygodny ${ }^{93}$.

Odrzuceniu prawdziwej wiary Bazyli przeciwstawiał radosne i chętne przyjęcie treści Credo chrzcielnego. Jest to odniesienie do błogosławieństwa dawnego Kościoła, gdy doktryna i praktyka życia były przykładne ${ }^{94}$. Przy formułowaniu nauki o Trójcy Świętej wskazuje na najgłębszą jedność, jaka istnieje - jedność Osób Boskich. To baza nie tylko doktrynalna, ale także

${ }^{83}$ Concilium Constantinopolitanum (381) can. 6, thum. T. Wnętrzak, w: Dokumenty Soborów Powszechnych (= DSP), t. 1: 325-787, układ i oprac. A. Baron-H. Pietras, ŹMT 24, Kraków 2002, 90-91. Odnośnie do tego soboru por. E. Chrysos, Die Akten des Konzils von Konstantinopel I (381), w: Romanitas-Christianitas. Festschrift J. Straub zum 70. Geburtstag, red. G. Wirth et al., Berlin New York 1982, 426-435; G. Bardy, Constantinople, concile de (381), DDC IV 424-428; A.M. Ritter, Konstantinopel. Ökumenische Synoden, I: Ökumenische Synode von 381, TRE XIX 518-524.

${ }^{84}$ Por. Basilius Caesarensis, In Mamantem martyrem 4.

${ }^{85}$ Por. Girardi, „Semplicità " e ortodossia, s. 58.

${ }^{86}$ Por. Basilius Caesarensis, De Spiritu Sancto I 2.

${ }^{87}$ Por. tenże, In Christi generationem 1.

${ }^{88}$ Por. Girardi, „Semplicità” e ortodossia, s. 73.

${ }^{89}$ Por. Basilius Caesarensis, In Psalmos hom. 44, 3. Tekst mówi o „wymiotach” (por. tamże, PG 29, 393C.

${ }^{90}$ Por. tenże, Moralia XLI.

${ }^{91}$ Por. tamże. Orygenes (In Josue hom. VII 6) mówił wyraźnie o wyłączeniu z Kościoła z powodu łamania dyscypliny eklezjalnej i zasad ewangelicznych.

${ }^{92}$ To argument używany przeciwko arianom i innym błędnowiercom. Por. Basilius Caesarensis, Adversus Eunomium I 2-3.

${ }^{93} \mathrm{~W}$ opisie heretyków Ojcowie Kościoła przywoływali jedną z reguł retorycznych sformułowanych w II w. przez mówcę Aleksandra (De figuris 23). Polegała ona na tym, że „gdy konfrontuje się bezpośrednio osoby lub rzeczy, opisujemy w żywy sposób nie tylko mowę, ale także wygląd, uczucia i cechy"; cyt. za L. Spengel, Rhetores Graeci, III, Lipsiae 1856, 25.

${ }^{94}$ Por. Basilius Caesarensis, Epistula 105 i 172. 
duchowa i praktyczna. Wielki Ojciec kapadocki zaangażował się przecież w wyeliminowanie podziałów wewnątrz Kościoła ${ }^{95}$, zachowującego ,jedność ducha w więzi pokoju (por. Ef 4, 3). [...] Nieposłuszeństwo okazywane Bogu przez wzajemną niezgodę jest niebezpieczne i zgubne" 96 - przestrzega biskup Cezarei Kapadockiej.

3. Wiara i konkretne wyzwania. Mimo specyfiki literatury epistolarnej i okazjonalnego charakteru listów, Bazyli niejednokrotnie ujawnia cechy teologa i nauczyciela wiary. W Listach wyraża głębokie przekonanie, że kontrowersje doktrynalne powinny być rozwiązywane na podstawie Pisma Świętego ${ }^{97}$. Kapadocczyk nie stronił od polemiki, występując przeciwko tym, którzy tworzyli błędne doktryny i ,z pomocą niektórych wyrażeń zaczerpniętych z apostoła [Pawła]” sformułowali ,niegodziwe sylogizmy”"98. Często heretycy po prostu okazywali złą wolę, nie chcąc uznać Chrystusa - Syna Bożego, zesłanego na świat przez Ojca ${ }^{99}$. Ta wskazówka dana Amfilochiosowi z Ikonium $^{100}$ staje się niemal kanoniczna.

Pisząc do innych osób Kapadocczyk kieruje gorące apele o szczere zaakceptowanie niektórych zasad wiary. Tak jest w długim i dramatycznym liście do Eustacjusza z Sebaste ${ }^{101}$, by ten przyjął nicejskie wyznanie wiary nie tylko co do litery, ale także co do ducha ${ }^{102}$. W tym piśmie znajduje się sformułowanie ciagle przewijające się w pismach Bazylego:

„Winniśmy tak chrzest przyjmować, jak nas pouczono, wierzyć jak nas ochrzczono i wysławiać Ojca, Syna i Ducha Świętego, jak w to wierzymy"103.

Tajemnica Trójcy Przenajświętszej ukazuje się stopniowo przez adorację $^{104}$. Wiara nie jest więc wyłącznie doktryną do przyjęcia, lecz zakorzenia się w doświadczeniu chrztu, wspólnocie Kościoła i w liturgii. Bazyli nie był wyjątkiem, jeśli chodzi o uwydatnianie wartości i znaczenia wiary przekazywanej

\footnotetext{
${ }^{95}$ Por. tenże, Epistula 70 i 243.

${ }^{96}$ Tenże, De iudicio 4, PG 31, 660B - 661A, ŹM 5, 74.

${ }^{97}$ Por. tenże, Epistula 188, 15-16; zob. też Courtonne, II, 131, nota 5. Podobne wskazówki zawiera Epistula 190, 3.

${ }^{98} \mathrm{~W}$ liście do mieszkańców Sozopolis (Epistula 261) Bazyli mówi o walentynianach i ich założycielu.

${ }^{99}$ Por. Basilius Caesarensis, Epistula 210, 3. W kontekście polemiczno-apologetycznym Bazyli cytuje J 5, 43 i Mt 28, 19, zob. Courtonne, II, 195.

${ }^{100}$ List 210 został napisany w 375 r. (por. Courtonne, III, 189). Bazyli (Epistula 210, 3, ed. Courtonne, II, 192, tłum. Krzyżaniak, s. 224) podkreśla, że sabelianizm to ,judaizm pod osłoną chrystianizmu usiłujący przeniknąć do ewangelicznych kerygmatów".

${ }^{101}$ Uważany za „ojca duchowego” Bazylego. Na temat Eustacjusza z Sebaste por. Ph. Rousseau, Basil of Caesarea, Berkeley 1998, 233-241.

102 Por. Penati Bernardini, La fede nei Padri Cappadoci, s. 196.

${ }^{103}$ Basilius Caesarensis, Epistula 125, 3, ed. Courtonne, II, 33, thum. Krzyżaniak, s. 156-157.

${ }^{104}$ Por. B. Studer, Dio salvatore nei Padri della Chiesa (Trinità - cristologia - soteriologia), Roma 1986, 218.
} 
podczas obrzędów chrzcielnych. Odniesienia tego typu były zresztą dosyć częste, a wyznanie wiary neofitów kierowało w pewnym sensie wywodami teologicznymi większości ówczesnych autorów ${ }^{105}$.

W celu obrony bóstwa Ducha Swiętego w kontrowersji pneumatologicznej ${ }^{106}$ Kapadocczyk oparł się na formule chrztu świętego i nakazie Chrystusa o nauczaniu i chrzcie „wszystkich narodów”: to polecenia Zbawcy, którymi od początku żył Kościół i które realizowali jego członkowie ${ }^{107}$. Także w innych kwestiach depozyt wiary winien być zachowany w całej swej pełni, bowiem „tak, jak otrzymaliśmy [go] od Pana, tak też jesteśmy ochrzczeni, tak, jak jesteśmy ochrzczeni, tak też oddajemy chwałę [Bogu]"108. Depozyt wiary winien pozostać nienaruszony ${ }^{109}$. O to stara się Bazyli, ukazując objawione prawdy, które Kościół pragnie ciagle kontemplować ${ }^{110}$. Bóg, w którego wierzymy to Deus absconditus. Takie jest przekonanie biskupa Cezarei.

W liście $234{ }^{111}$ Kapadocczyk odpowiada na dylemat anomejczyków: „Czy wielbisz, to co znasz, czy też Tego, którego nie znasz"112. Biskup Cezarei przytacza najpierw argumenty o charakterze teologicznym i rozumowym odnoszące się do poznania Boga i oddawania Mu czci ${ }^{113}$.

„Wiem, że istnieje. Czym jest zaś jego substancja, sądzę, że to przewyższa nasz intelekt? Jak więc jestem zbawiony? Dzięki wierze. Wiary wystarczy, aby wiedzieć, że Bóg istnieje, nie Kim jest oraz, iż wynagradza tych, którzy go szukają"114.

Argumenty biblijne zostają przytoczone w ostatniej części listu. Kluczową rolę odgrywa $\mathrm{J}$ 1, 18. W oparciu o ten tekst Bazyli wyjaśnia:

„Według słów Pisma Świętego: «Boga nikt nigdy nie widział. Syn Jednorodzony ${ }^{115}$, który jest na łonie Ojca, ten nam opowiedział» (J 1, 8). Jakież to pouczenie o Ojcu dał Syn Jednorodzony? O Jego istocie czy wszechmocy?

${ }^{105}$ Por. rozwinięcie tej kwestii wg E. Ferguson, Baptism in the Early Church: History, Theology and Liturgy in the First Five Centuries, Grand Rapids - Cambridge 2009, 583-584.

${ }^{106}$ Por. W. Turek, ,, Wierzymy w Ojca, i Syna, i Ducha Świętego”: bóstwo i pochodzenia Ducha Świętego w ujęciu św. Bazylego Wielkiego († 379), StPł 28 (2000) 49-56.

${ }^{107}$ Por. Basilius Caesarensis, De Spiritu Sancto X 26; XV 34.

${ }^{108}$ Tenże, Epistula 251, 4, ed. Courtonne, III, 92, tłum. własne.

${ }^{109}$ Wskazanie na sakrament chrztu jako na normatywny sposób wyrażania wiary można znaleźć w: Basilius Caesarensis, Adversus Eunomium II 22; III 2; III 5; De Spiritu Sancto X 26; Epistula 152, 2; 175; 251, 4; Contra Sabelianos, Arium et Anomeos 4.

${ }^{110}$ Por. tenże, Homilia de fide 1.

${ }^{111}$ Jeden z listów skierowanych do Amfilochiosa.

${ }^{112}$ Basilius Caesariensis, Epistula 234, 1, ed. Courtonne, III, 43, tłum. Krzyżaniak, s. 274.

${ }^{113}$ Por. Courtonne, III, 42, nota 1.

${ }^{114}$ Basilius Caesarensis, Epistula 234, 2, ed. Courtonne, III, 43, thum. Krzyżaniak, s. 276. Na temat tego fragmentu por. Penati Bernardini, La fede nei Padri Cappadoci, s. 197.

${ }^{115}$ Por. Basilius Caesarensis, Epistula 125, 3, ed. Courtonne, II, 34, thum. Krzyżaniak, s. 156: „Z przekazanej nam przez Tradycję wiary dowiedzieliśmy się, że Jeden jest Jednorodzony”. 
Jeśli o wszechmocy, to tyle o tym wiemy, ile nas pouczył. A jeśli o istocie, to powiedz, gdzież to Syn orzekł, iż «nie-zrodzoność» jest istotą Boga?"116.

Kapadocczyk proponuje dalej wywód o strukturze chiazmatycznej, bowiem wiara zakłada poznanie, a człowiek przez poznanie dochodzi do wiary ${ }^{117}$.

Następnie Bazyli wskazuje, że cześć oddawana Bogu wynika z wiary, którą On sam umacnia. To Jego jedyne i niepowtarzalne powołanie, jak w przypadku Abrahama ${ }^{118}$. Dla Kapadocczyka wiara i poznanie Prawdy są ze sobą nierozłącznie związane.

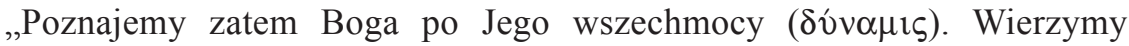
więc w Tego, którego poznaliśmy, a korzymy się przed Tym, w którego uwierzyliśmy" 119 .

Nierozdzielność Osób wyraża inwokacja chrzcielna i z tą myślą mówi się o współuwielbieniu. Bazyli przenosi to do liturgii i zastępuje doksologię „Chwała Ojcu przez Syna w Duchu Świętym” inną: „Chwała Ojcu i Synowi i Duchowi Świętemu”. Wprowadza w ten sposób rozróżnienie osób i uwydatnia ich równość ${ }^{120}$, ponieważ:

„naturalna dobroć i świętość natury, i królewska godność, przenikają do Ducha od Ojca przez Jednorodzonego" $"$.

Biskup kapadocki waloryzuje znaczenie drogi spekulatywnej w refleksji nad zasadami wiary, jednak punktem wyjścia i akordem końcowym rozważań jest tekst biblijny ${ }^{122}$. W jego ujęciu konkretne sformułowanie wiary to Credo nicejskie, do którego prowadzą prawdy biblijne ${ }^{123}$. Dla Bazylego wyznanie wiary Ojców Nicejskich wyraża zarówno wierność Pismu Świętemu, jak i tradycji apostolskiej. Uważa nicejskie wyznanie wiary za obowiązujące, ścisłe

${ }^{116}$ Tenże, Epistula 234, 3, ed. Courtonne, III, 43, thum. Krzyżaniak, s. 276. W De Spiritu Sancto (XVIII 47) pojawia się ta sama tematyka. Teksty biblijne, do których odwołuje się Kapadocczyk są jednak inne: Mt 11, 27 (to dla niego odpowiednik J 1, 18) i 1Kor 12, 3.

${ }^{117}$ Por. tenże, Epistula 234, 3.

${ }^{118}$ Wzmiankowany w kontekście wiary w tenże, Epistula 234, 3, Na temat interpretacji postaci wielkiego patriarchy por. F. Cocchini, Abramo, NDPAC I 21-23.

${ }^{119}$ Basilius Caesarensis, Epistula 234, 2, ed. Courtonne, III, 43, tłum. Krzyżaniak, s. 277. List został napisany w roku 376. Por. Courtonne, III, 41.

${ }^{120}$ Kapadocczyk podkreśla, że opierał się na Tradycji Ojców i nie wprowadzał podejrzanych nowości. Por. E. Cavalcanti, L'esperienza di Dio nei Padri Greci. Il trattato „Sullo Spirito Santo” di Basilio di Cesarea, La spiritualità cristiana. Storia e testi 5, Roma 1984, 57-58.

${ }^{121}$ Basilius Caesarensis, De Spiritu Sancto XVII 47, SCh 17bis, 197, thum. Brzóstowska, s. 149.

${ }^{122}$ Bazyli rozpoczyna od parafrazy J 4, 22 (por. Epistula 234, 1). Wśród tekstów końcowej partii wywodu znajduje się J 1, 18.

${ }^{123}$ Tekst Mt 9, 28 zharmonizowany z J 9, 38 wskazuje na przejście od adoracji do wyznania wiary. Por. Basilius Caesarensis, Epistula 234, 3. 
i ortodoksyjne. Cytuje je w dwóch listach: $125^{124}$ i $140^{125}$. To właśnie dzięki pogłębieniu terminologii trynitarnej i chrystologicznej Nicei osiaggnięto porozumienie z Zachodem w kwestii pneumatologicznej po 381 r., co zaowocowało wspólną formułą wiary ${ }^{126}$. Podobnie jak wiara trynitarna, tak i pneumatologia bazyliańska łączy się z teologią chrztu: udzielony w imię Trójcy, powoduje, że zgodnie z wiarą wyznaje się Ojca i Syna i Ducha Świętego. Ten ostatni „nie jest obcy naturze Boga" ${ }^{27}$.

Bazyli wskazuje, że cześć oddawana Bogu wynika z wiary, którą On umacnia. To Jego osobiste powołanie, jak w przypadku Abrahama. Dla Kapadocczyka wiara i poznanie Prawdy są z sobą nierozłącznie związane.

„Ukorzenie się przed Bogiem idzie za wiarą, a wiara ta umacnia się przez oznaki wszechmocy. A jeśli orzekasz, że ten, kto wierzy, zna również Boga, to zna on Go z tego, w co wierzy, lub, nawet na odwrót, wierzy w Niego na podstawie tego, po czym Go poznaje. Poznajemy zatem Boga po Jego wszechmocy. Wierzymy więc w Tego, którego poznaliśmy, a korzymy się przed Tym, w którego uwierzyliśmy"128.

Według Bazylego wiara jest wspomagana przez rozum, a adoracja stanowi owoc wiary. Ponadto ukazuje motywacje drogi do Boga w perspektywie racjonalnej i psychologicznej.

Kapadocczyk zdawał sobie doskonale sprawę, że w trudnych czasach, gdy atakowano z każdej strony prawowierność, zbyt pojednawcze nastawienie mogło szkodzić i wprowadzać zamęt. To powód, dla którego Cezarejczyk w pewnym okresie swoich zmagań o treść Credo nie czyni już subtelnych rozróżnień jeśli chodzi o stopień wspólnoty w wierze, ale potępia każda formęjej kontestacji: nadszedł czas ,wielkiego odstępstwa" i antychrysta ${ }^{129}$. Gdy musiał bronić się przed oskarżeniami niewłaściwego sformułowania wiary, czynił to głosząc

${ }^{124}$ Por. Basilius Caesarensis, Epistula 125, 2, ed. Courtonne, II, 32-33, thum. Krzyżaniak, s. 155-156: „Wierzymy w jednego Boga, Ojca wszechmogącego, Stworzyciela wszystkich rzeczy widzialnych i niewidzialnych oraz w jednego Pana, Jezusa Chrystusa, Syna Bożego, Jednorodzonego, zrodzonego z Ojca czyli z substancji Ojca, Boga z Boga, Światłość ze Światłości, Bóg prawdzi-

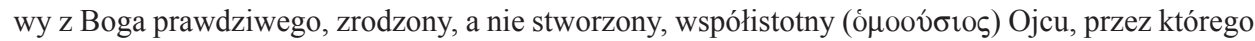
wszystko się stało, czy to co w niebiosach czy to co na ziemi, który dla nas ludzi i dla naszego zbawienia zstapił [na ziemię] i przybrał ciało; stał się człowiekiem, cierpiał, trzeciego dnia zmartwychwstał, wstąpił na niebiosa, który ponownie przyjdzie sądzić żywych i umarłych. [Wierzymy] także w jednego Ducha Świętego. Odnośnie do tych, którzy mówią, że był czas gdy Syn Boży nie istniał, że nie było Go zanim nie został zrodzony i utrzymują, że powstał z niebytu lub jest innej

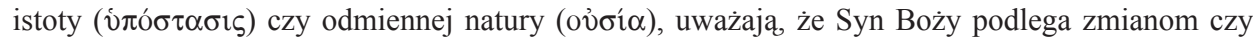
odmianie, tych wszystkich Kościół katolicki i apostolski piętnuje anatemą".

${ }^{125}$ Por. tenże, Epistula 140, 2, ed. Courtonne, II, 61-62.

${ }^{126}$ Por. M. Simonetti, Genesi e sviluppo della dottrina trinitaria di Basilio di Cesarea, w: Basilio di Cesarea, I, s. 169-197.

${ }^{127}$ Basilius Caesarensis, Epistula 159, 2, ed. Courtonne, II, 86, tłum. Krzyżaniak, s. 174.

${ }^{128}$ Tenże, Epistula 234, 3, ed. Courtonne, III, 43, tłum. Krzyżaniak, s. 276-277.

${ }^{129}$ Por. tenże, Epistula 264. 
prawdę Bożą „,bez szukania kości niezgody”130. W przypadku biskupa Cezarei Kapadockiej te słowa mogą stanowić najwłaściwsze podsumowanie jego zmagań o prawowierność i rozważań dotyczących właściwych formuł wiary.

Bazyli Wielki, na równi z innymi Ojcami Kościoła, wskazywał, że wiara nie powinna zatrzymywać się na czysto abstrakcyjnych sformułowaniach, lecz ma odnosić się do przeżywanych tajemnic. Widać to w odwoływaniu się naszego autora do chrzcielnego wyznania wiary i Credo nicejskiego. Prawowierna doktryna została uwydatniona i dowartościowana w obliczu herezji i błędów, chociaż wyjaśnianie prawd Objawienia i dogmatów zawsze stanowiło podstawowe zadanie Wielkiego Kościoła. Kapadocczyk z pewnością nie był inicjatorem dyskusji teologicznych rozpalających umysły ówczesnej epoki, a w wielu kwestiach doktrynalnych to nie on wypowiedział ostatnie słowo. Kluczowe są jednak wytyczone przez niego kierunki refleksji trynitarnej, chrystologicznej i pneumatologicznej. W ocenie Ojca kapadockiego wiara miała być konkretnie przeżywana, a nie stanowić wyłącznie przedmiot akademickich dyskusji. W całej swej prostocie ma ona zadanie „funkcjonalne": prowadzi do zbawienia oraz daje możliwość stopniowego odkrywania tajemnicy Boga.

Po okresie ożywionych dyskusji i jednoznacznego świadectwa, nastapiła epoka formalizmu doktrynalnego. Wtedy właśnie pojęcia odnoszące się do nadprzyrodzonej rzeczywistości zaczynały być analizowane w sposób wyłącznie formalny i w oderwaniu od dogmatów, które wyrażały. Gdy w końcu formuły doktrynalne skostniały, stały się wyłącznie oznakami przynależności czy kontestacji, nie zaś ekspresją przeżywanej wiary, do czego dążył Bazyli.

\section{FAITH IN THE LETTERS OF ST. BASIL THE GREAT}

\section{(Summary)}

The article is an examination of Basil's teaching about faith and its importance in his large correspondence. The bishop of Caesarea describes faith as the acceptance of the Gospel, the conviction of the truth of the message, a confession of one's belief in the Trinity. The Cappadocian emphasizes faith as an acceptance and conviction of the truth which comes from the inspired Scriptures and the teaching of the Nicaea. The confession of faith formulated by the Council of Nicaea constituted the essence of the truth of the Christian faith. The bishop of Caesarea indicates the importance of the baptismal formula for the formulation of the true Christian doctrine. During the baptismal rite the baptizand makes their confession of faith and is thus admitted into the community of the faithful.

${ }^{130}$ Tenże, Epistula 223, 5, ed. Courtonne, III, 14, tłum. Krzyżaniak, s. 255. 
Basil's teaching of initiation into the Christian mistery is dominated by his use of the word mean the apostolic doctrines which constitute what the "Great Church" taught and believed. The Cappadocian points to the danger of false and heretical assemblies (parasynagogues) and of the false teachers of the faith. It is presented as a way of knowing God. There is also one important emphasis in Basil's thought which especially characterizes his view of the human steps in the concrete realization of it: the knowledge of God and faith in Him is manifested in love to God and one's neighbor.

Key words: Faith, Basil the Great, Credo, Letters.

Stowa kluczowe: wiara, Bazyli Wielki, Credo, listy. 
